\title{
Structure of $\left(\eta^{5}\right.$-Cyclopentadienyl) $\left(\eta^{6}\right.$-thianthrene)iron(II) Hexafluorophosphate
}

\author{
By K. A. Abboud, V. M. Lynch and S. H. Simonsen* \\ Department of Chemistry, University of Texas at Austin, Austin, TX 78712, USA \\ AND A. Piórko AND R. G. Sutherland \\ Department of Chemistry, University of Saskatchewan, Saskatoon, Saskatchewan, S7N 0W0, Canada
}

(Received 20 June 1989; accepted 8 September 1989)

Abstract. $\left[\mathrm{Fe}\left(\mathrm{C}_{5} \mathrm{H}_{5}\right)\left(\mathrm{C}_{12} \mathrm{H}_{8} \mathrm{~S}_{2}\right)\right]\left[\mathrm{PF}_{6}\right](\mathrm{I}), M_{r}=482 \cdot 22$, monoclinic, $P 2_{1} / c, a=14.194$ (3), $b=9.617$ (2), $c=$ 25.971 (5) $\AA, \beta=100 \cdot 31(2)^{\circ}, V=3488$ (1) $\AA^{3}, Z=8$ (two molecules per asymmetric unit), $D_{x}=$ $1.836 \mathrm{~g} \mathrm{~cm}^{-3}, \quad$ Mo $K \alpha \quad(\lambda=0.70169 \AA), \quad \mu=$ $12.429 \mathrm{~cm}^{-1}, \quad F(000)=1936, \quad T=163 \mathrm{~K}$. Blockmatrix least-squares refinement of (I) converged to $R$ $=0.044$ and $w R=0.040$ using 3785 reflections with $I$ $>3 \sigma(I)$. The dihedral angles of the two molecules in the asymmetric unit are different. In molecule $A$, the $\mathrm{FeCp}$ moiety ( $\mathrm{Cp}=$ cyclopentadiene) is inside the fold with a dihedral angle of $143 \cdot 1(2)^{\circ}$, whereas in molecule $B$, the $\mathrm{FeCp}$ moiety is located outside the fold with a dihedral angle of $136 \cdot 3(2)^{\circ}$.

Introduction. In a continuation of our study on the synthesis, structure and properties of the FeCp complexes of tricyclic heterocycles, the structure of (I)

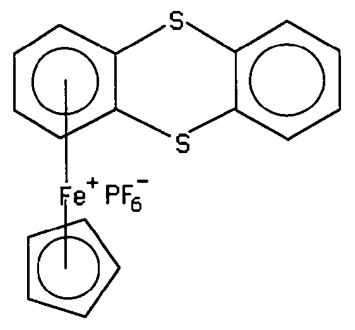

(I)

was determined. A method of synthesis (Scheme 1) different from the one used in the synthesis (Scheme 2) of the 2-methyl homologue (Sutherland, Piórko, Gill \& Lee, 1982), for which the crystal structure has been elucidated (Simonsen, Lynch, Sutherland \& Piórko, 1985), was employed. The objective of the present study was to determine whether the change in the method of synthesis, as well as the presence of a methyl substituent, would have any effect on the geometry of the heterocycle in the complex.

* To whom correspondence should be addressed.

0108-2701/90/061018-05\$03.00
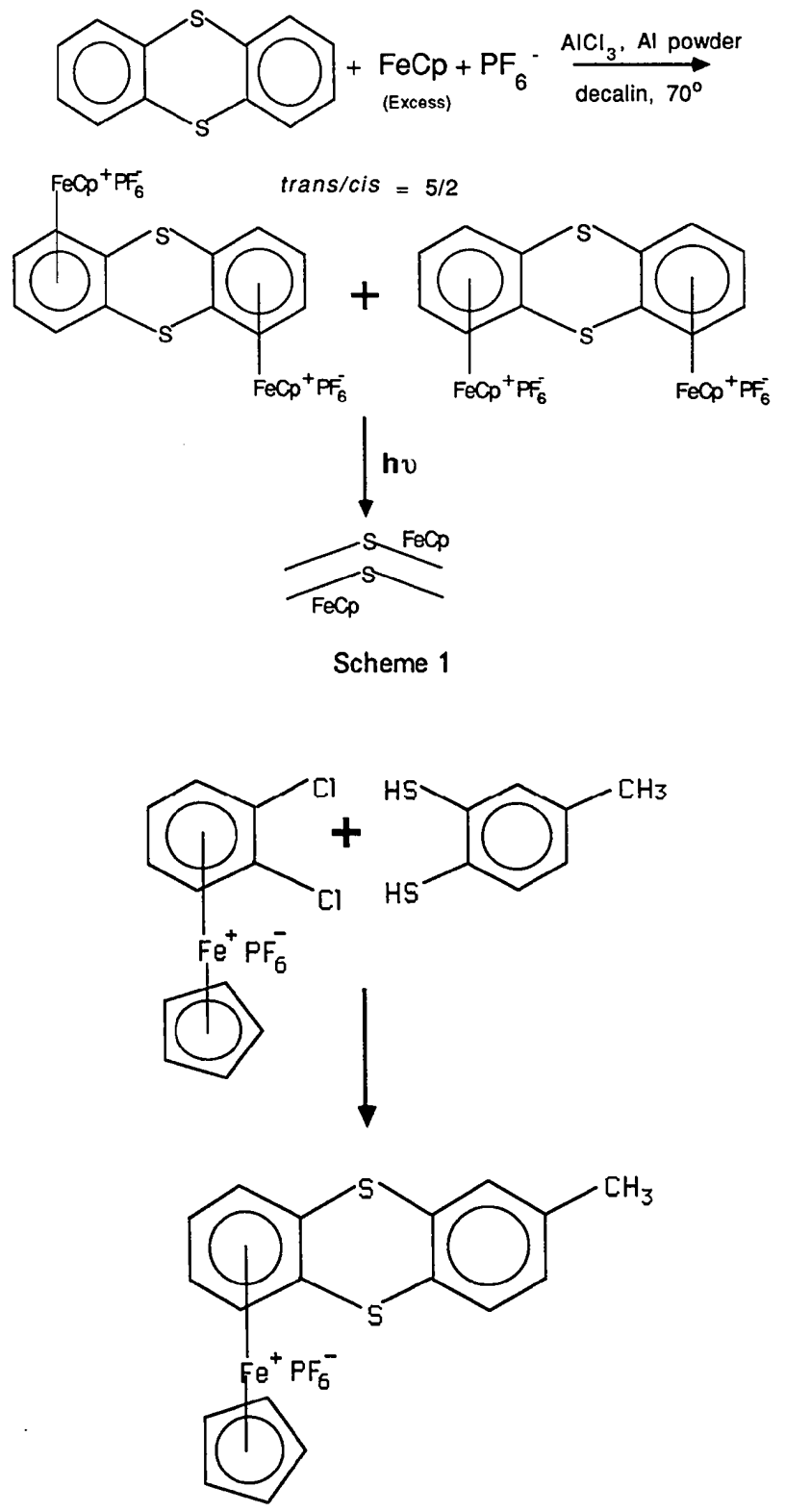

Scheme 2

(C) 1990 International Union of Crystallography 
Experimental. The title compound was obtained from the monodemetallation reaction of a $2: 5 \mathrm{mix}$ ture of $c i s$ and trans- $\left(\eta^{6}, \eta^{6}\right.$-thianthrene)bis[(Cp)iron(II)] hexafluorophosphate by light in an acetonediethylether-methylene chloride solution. The preparation of the dicationic mixture was reported by Lee, Piórko \& Sutherland (1983). Crystals of the thianthrene monocations were grown from the resulting solution at $c a 255 \mathrm{~K}$. A needle-shaped orange-yellow crystal, $0.10 \times 0.21 \times 0.50 \mathrm{~mm}$, was mounted and transferred to a Syntex $P 2_{1}$ diffractometer equipped with a graphite monochromator utilizing Mo $K \alpha(\lambda$ $=0.71069 \AA$ ) radiation, where it was maintained in an environment of dry $\mathrm{N}_{2}$ at $163 \mathrm{~K}$ using a Syntex LT-1 low-temperature delivery system. Preliminary investigations revealed the crystal system to be monoclinic. 45 strong reflections, $20.68 \leq 2 \theta \leq$ $26.87^{\circ}$, were used to refine the unit-cell parameters. 13497 reflections $(h-17 \rightarrow 17 ; k-11 \rightarrow 11 ; l 0 \rightarrow 32)$ were collected using the $\omega$-scan method, 6849 unique reflections, $R_{\text {int }}=0.019 ; 2 \theta$ range $4 \rightarrow 52^{\circ}, 1^{\circ} \omega$ scan at $6-12^{\circ} \mathrm{min}^{-1}$, depending upon intensity. Four reflections $(006 ; 00 \overline{6} ; 200 ; \overline{2} \overline{1} \overline{1})$ were remeasured every 96 reflections to monitor instrument stability and crystal decay (maximum correction on $I$ was $<$ $1.75 \%)$. Absorption corrections were applied based on measured crystal faces (Riley \& Davis, 1976); min. and max. transmission factors 0.773 and 0.900 . The structure was solved by the heavy-atom method [Patterson, SHELX76 (Sheldrick, 1976)] which revealed the positions of the $\mathrm{Fe}$ atoms in both molecules of the asymmetric unit (molecules $A$ and $B$ ). The positions of the rest of the non- $\mathrm{H}$ atoms were obtained from a difference Fourier map and all $\mathrm{H}$ atoms were obtained from a subsequent difference map. Refinement was carried out by block-matrix least squares (each molecule was refined in a separate block) in SHELX76 using anisotropic thermal parameters for the non- $\mathrm{H}$ atoms and isotropic thermal parameters for the $\mathrm{H}$ atoms. $\sum w\left(\left|F_{o}\right|-\left|F_{c}\right|\right)^{2}$ was minimized, where $w=1 /\left(\sigma\left|F_{o}\right|\right)^{2}, \quad \sigma\left(F_{o}\right)=$ $0.5 k I^{-1 / 2}\left\{[\sigma(I)]^{2}+(0 \cdot 02)^{2}\right\}^{1 / 2}, I$ (intensity) $=\left(I_{\text {peak }}-\right.$ $\left.I_{\text {bkg }}\right) \times($ scan rate $)$, and $\sigma(I)=\left(I_{\text {peak }}+I_{\text {bkg }}\right)^{1 / 2} \times($ scan rate). $k$ is the correction due to decay and $L p$ effects, and 0.02 is a factor used to downweight intense reflections and to account for instrument instability. Convergence was attained with $R$ and $w R$ of 0.044 and $0 \cdot 040$, respectively, for 3785 reflections of intensity larger than $3 \sigma(I)$. In the last cycle of refinement, 591 variables were refined to a goodness-of-fit of $1 \cdot 18$; the largest shift/e.s.d. did not exceed $0 \cdot 1$; min. and max. peaks in the difference Fourier map were -0.44 and $0.54 \mathrm{e} \AA^{-3}$, respectively. The linear absorption coefficient was calculated from values from International Tables for X-ray Crystallography (1974); scattering factors for non- $\mathrm{H}$ atoms were taken from Cromer \& Mann (1968) with anomalous- dispersion corrections from Cromer \& Liberman (1970), while those of $\mathrm{H}$ atoms were from Stewart, Davidson \& Simpson (1965). The least-squares planes program was supplied by Cordes (1983); other programs used are cited in reference 11 of Gadol \& Davis (1982). Positional parameters of all non-H atoms with equivalent isotropic thermal parameters are given in Table 1. Bond lengths and angles for the non-H atoms are listed in Table 2.* Figs. 1 and 2 show the thermal ellipsoid drawings (SHELXTL$P L U S$ ) of molecules $A$ and $B$, respectively, with the atomic labeling schemes. The packing diagram is shown in Fig. 3.

Discussion. In both molecules of the asymmetric unit, the $\mathrm{Fe}$ atom is centered above the $\mathrm{Cp}$ ring; however, bonding between $\mathrm{Fe}$ and the arene rings is asymmetrical. The longest $\mathrm{Fe}-\mathrm{C}$ distances are to the $\mathrm{C}$ atoms adjacent to the $\mathrm{S}$ atoms. The $\mathrm{Fe}-\mathrm{C} 4 a$ and $\mathrm{Fe}-\mathrm{Cl} 10 a$ distances are $2 \cdot 100(5)$ and $2.098(6) \AA$ in $A$, and 2.092 (5) and $2.081(5) \AA$ in $B$, as compared to the average 2.078 (6) $\AA \mathrm{Fe}$-arene $\mathrm{C}$ distance in $A$ and $2.076(6) \AA$ in $B$. This indicates that the $\mathrm{Fe}$ atoms are not exactly centered on the arene rings. The $\mathrm{C}-\mathrm{C}$ distances of the coordinated arenes are longer than the $\mathrm{C}-\mathrm{C}$ distances of the uncoordinated rings in both molecules. This phenomenon was also observed in similar compounds reported by Simonsen et al. (1985) and Lynch, Thomas, Simonsen, Piórko \& Sutherland (1986).

The distances between $\mathrm{Fe}$ and the $\mathrm{Cp}$ rings, $1.6702(7)$ and $1.6650(8) \AA$ in $A$ and $B$, respectively, are longer than the distances between $\mathrm{Fe}$ and the coordinated arene ring planes $[1.5385(7)$ and $1.5336(8) \AA$ in $A$ and $B$, respectively]. All these distances are well within the range of distances observed in similar compounds (Lynch et al., 1986; Simonsen et al., 1985). The dihedral angles between the $\mathrm{Cp}$ ring planes and the coordinated arenes [2.5 (2), $1.5(2)^{\circ}$ in $A$ and $B$, respectively] are both less than $3^{\circ}$ which was observed in compounds reported by Simonsen et al. (1985) and Lynch et al. (1986). The largest angle is in $A$ where the $\mathrm{FeCp}$ moiety is inside the fold.

In a previous paper, the crystal structure of (5a,6,7,8,9,9a- $\eta^{6}$-2-methylthianthrene) $\left(\eta^{5}\right.$-Cp)iron(II) hexafluorophosphate (II), prepared in a double nucleophilic substitution reaction from an $o$-chlorobenzene complex as a starting material, was described (Simonsen et al., 1985). It was found that

\footnotetext{
* Tables of the crystallographic data, anisotropic thermal parameters, $\mathrm{H}$-atom parameters, bond lengths and angles involving $\mathrm{H}$ atoms, and structure-factor amplitudes have been deposited with the British Library Document Supply Centre as Supplementary Publication No. SUP 52632 (50 pp.). Copies may be obtained through The Technical Editor, International Union of Crystallography, 5 Abbey Square, Chester CH1 2HU, England.
} 
Table 1. Fractional coordinates and equivalent isotropic thermal parameters $\left(\AA^{2}\right)$

\begin{tabular}{|c|c|c|c|c|}
\hline & & $=(1 / 3) \sum_{i} \sum_{j} U_{i j}$ & $a_{j}^{*} \mathbf{a}_{i} \cdot \mathbf{a}_{j}$ & \\
\hline & $x$ & $y$ & $z$ & $U_{\text {oq }}$ \\
\hline Molec & & & & \\
\hline $\mathrm{Fe}$ & $0.26044(5)$ & $0.13282(8)$ & $-0 \cdot 15713(3)$ & $0.0205(2)$ \\
\hline $\mathbf{P}$ & $-0.00443(10)$ & $-0.1215(2)$ & $0.33224(5)$ & $0.0244(5)$ \\
\hline F1 & $-0.0240(2)$ & $-0.0195(4)$ & 0.28284 (13) & $0.0422(13)$ \\
\hline F2 & $0.0148(2)$ & $-0.2248(4)$ & $0.38179(13)$ & $0.0404(13)$ \\
\hline F3 & $0 \cdot 1070(2)$ & $-0.1271(4)$ & 0.32906 (12) & 0.0358 (12) \\
\hline F4 & $0.0146(2)$ & $0.0094(4)$ & $0.37065(14)$ & $0.0431(13)$ \\
\hline F5 & $-0.1162(2)$ & $-0.1162(3)$ & $0.33585(12)$ & $0.0359(12)$ \\
\hline F6 & $-0.0235(2)$ & $-0.2536(4)$ & $0.29446(14)$ & 0.0484 (14) \\
\hline S5 & $0.34874(10)$ & $0.05936(15)$ & $-0.02258(5)$ & $0.0251(5)$ \\
\hline S10 & $0.11644(10)$ & $0.0306(2)$ & $-0.06471(6)$ & $0.0282(5)$ \\
\hline $\mathrm{Cl}$ & $0 \cdot 1661(4)$ & $-0.0328(6)$ & $-0.1590(2)$ & 0.028 (2) \\
\hline $\mathrm{C} 2$ & 0.2300 (4) & $-0.0593(6)$ & $-0.1927(2)$ & $0.030(2)$ \\
\hline C3 & $0.3288(4)$ & $-0.0481(6)$ & $-0.1749(2)$ & $0.029(2)$ \\
\hline $\mathrm{C} 4$ & 0.3644 (4) & $-0.0070(6)$ & $-0.1231(2)$ & $0.026(2)$ \\
\hline $\mathrm{C} 4 A$ & 0.2998 (4) & $0.0166(5)$ & $-0.0882(2)$ & $0.021(2)$ \\
\hline $\mathrm{C} 5 \mathrm{~A}$ & 0.2655 (4) & 0.1812 (5) & $-0.0064(2)$ & $0.021(2)$ \\
\hline C6 & $0.2992(4)$ & $0 \cdot 2860(6)$ & $0.0290(2)$ & $0.027(2)$ \\
\hline C7 & $0.2366(4)$ & $0.3748(6)$ & $0.0472(2)$ & $0.030(2)$ \\
\hline $\mathrm{C} 8$ & $0 \cdot 1403(4)$ & $0.3656(7)$ & $0.0285(2)$ & $0.034(2)$ \\
\hline $\mathrm{C} 9$ & $0 \cdot 1057(4)$ & $0.2637(7)$ & $-0.0079(2)$ & $0.033(2)$ \\
\hline $\mathrm{C} 9 \mathrm{~A}$ & $0 \cdot 1674(4)$ & $0 \cdot 1688(5)$ & $-0.0244(2)$ & $0.022(2)$ \\
\hline $\mathrm{ClOA}$ & 0.2004 (4) & 0.0040 (5) & $-0.1064(2)$ & $0.022(2)$ \\
\hline $\mathrm{Cll}$ & $0 \cdot 1704$ (4) & $0.2917(6)$ & $-0.1884(2)$ & $0.028(2)$ \\
\hline $\mathrm{C} 12$ & $0.2227(4)$ & $0.3320(6)$ & $-0.1396(2)$ & $0.027(2)$ \\
\hline $\mathrm{C} 13$ & $0.3223(4)$ & $0.3248(6)$ & $-0.1424(2)$ & $0.029(2)$ \\
\hline C14 & $0 \cdot 3292$ (4) & $0.2819(6)$ & $-0.1931(2)$ & $0.029(2)$ \\
\hline $\mathrm{Cl5}$ & $0.2356(4)$ & $0 \cdot 2607(6)$ & $-0.2216(2)$ & $0.027(2)$ \\
\hline Mole & & & & \\
\hline $\mathrm{Fe}$ & $0.22338(5)$ & $0.90093(8)$ & $0 \cdot 15244(3)$ & $0.0203(2)$ \\
\hline$P$ & $0.53346(10)$ & 0.9057 (2) & $0 \cdot 30340(5)$ & $0.0237(5)$ \\
\hline F1 & $0.5727(2)$ & 0.9038 (4) & 0.36483 (12) & $0.0468(13)$ \\
\hline F2 & $0.4946(2)$ & 0.9068 (4) & $0.24162(12)$ & $0.0452(13)$ \\
\hline F3 & $0.5363(2)$ & $1.0705(3)$ & 0.30309 (14) & 0.0470 (14) \\
\hline F4 & 0.6411 (2) & 0.9017 (4) & 0.29322 (12) & $0.0428(13)$ \\
\hline F5 & 0.5307 (2) & $0.7408(4)$ & $0.3028(2)$ & $0.0545(15)$ \\
\hline F6 & $0.4263(2)$ & 0.9088 (4) & $0.31401(12)$ & 0.0419 (13) \\
\hline S5 & 0.39338 (9) & $0.7434(2)$ & $0.09111(5)$ & $0.0257(5)$ \\
\hline S10 & $0.17270(9)$ & $0.73099(15)$ & $0.03439(5)$ & $0.0247(5)$ \\
\hline $\mathrm{Cl}$ & $0.1543(4)$ & $0.9832(6)$ & $0.0817(2)$ & $0.023(2)$ \\
\hline $\mathrm{C} 2$ & $0 \cdot 1855(4)$ & $1.0907(6)$ & $0.1165(2)$ & $0.030(2)$ \\
\hline $\mathrm{C} 3$ & 0.2806 (4) & $1.0950(6)$ & $0.1422(2)$ & $0.028(2)$ \\
\hline C4 & 0.3451 (4) & $0.9926(6)$ & $0 \cdot 1333(2)$ & $0.024(2)$ \\
\hline$C A A$ & 0.3145 (3) & 0.8819 (6) & $0.0978(2)$ & $0.020(2)$ \\
\hline $\mathrm{C} 5 A$ & $0.3613(4)$ & 0.7088 (5) & 0.0237 (2) & $0.021(2)$ \\
\hline C6 & $0.4326(4)$ & 0.6819 (6) & $-0.0054(2)$ & $0.025(2)$ \\
\hline C7 & 0.4096 (4) & $0.6484(6)$ & $-0.0581(2)$ & $0.031(2)$ \\
\hline C8 & $0.3146(4)$ & $0.6466(6)$ & $-0.0827(2)$ & $0.028(2)$ \\
\hline $\mathrm{C} 9$ & 0.2434 (4) & $0.6754(6)$ & $-0.0543(2)$ & $0.027(2)$ \\
\hline$C 9 A$ & 0.2663 (4) & $0.7047(5)$ & $-0.0012(2)$ & $0.021(2)$ \\
\hline $\mathrm{C} 10 \mathrm{~A}$ & $0.2169(3)$ & $0.8775(6)$ & $0.0722(2)$ & 0.019 (2) \\
\hline $\mathrm{C} 11$ & $0.1202(5)$ & $0.7776(7)$ & $0.1755(2)$ & $0.039(2)$ \\
\hline $\mathrm{Cl} 2$ & $0.2057(5)$ & $0.7031(6)$ & 0.1773 (2) & 0.038 (3) \\
\hline $\mathrm{C} 13$ & $0.2784(5)$ & $0.7695(6)$ & $0.2120(2)$ & $0.030(2)$ \\
\hline $\mathrm{C} 14$ & 0.2373 (4) & $0.8860(7)$ & 0.2323 (2) & $0.030(2)$ \\
\hline $\mathrm{C} 15$ & $0.1404(4)$ & $0.8913(7)$ & $0.2094(2)$ & 0.035 (2) \\
\hline
\end{tabular}

Molecule $A$

1 2 2

$\begin{array}{ll}\mathrm{C} 1 & \mathrm{Fe} \\ \mathrm{C} 2 & \mathrm{Fe}\end{array}$

C4

C4 4 A

C10A

C11

C12

$\mathrm{C} 13$

C14

F1

F1

F1

F1

F2

F2

F2

F3

F3

F4

F4
F5

F6

$\mathrm{C} 4 A$

C5A

$\mathrm{C} 9 A$
$\mathrm{C} 10 A$

C2

C10A

$\mathrm{C} 3$
$\mathrm{C} 4$

C4

$\mathrm{C} 4 \mathrm{~A}$
$\mathrm{C} 10 \mathrm{~A}$

C10A

S5
C6

C6

C9A

C7

C8
C9

C9A

S10

$\mathrm{S} 10$
$\mathrm{C} 5 \mathrm{~A}$

S10

S10

$\mathrm{C} 1$
$\mathrm{C} 12$
$\mathrm{C} 15$

$\mathrm{C} 12$
$\mathrm{C} 15$

C13
C14

C14
C15

C11

Molecule

Molecule $B$

$\begin{array}{lr}1 & 2 \\ \text { C1 } & \text { Fe } \\ \text { C2 } & \text { Fe } \\ \text { C3 } & \text { Fe } \\ \text { C4 } & \text { Fe } \\ \text { C4A } & \text { Fe } \\ \text { C10A } & \text { Fe } \\ \text { C11 } & \text { Fe } \\ \text { C12 } & \text { Fe } \\ \text { C13 } & \text { Fe } \\ \text { C14 } & \text { Fe } \\ \text { C15 } & \text { Fe } \\ \text { F1 } & \text { P } \\ \text { F1 } & \text { P } \\ \text { F1 } & \text { P } \\ \text { F1 } & \text { P } \\ \text { F2 } & \text { P } \\ \text { F2 } & \text { P } \\ \text { F2 } & \text { P } \\ \text { F2 } & \text { P } \\ \text { F3 } & \text { P } \\ \text { F3 } & \text { P } \\ \text { F3 } & \text { P } \\ \text { F4 } & \text { P } \\ \text { F4 } & \text { P }\end{array}$

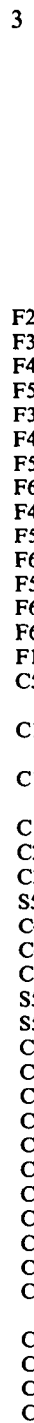$$
1-2
$$

2.076 (6)

$2.077(6)$

2.084 (6)

2.073 (5)

$2 \cdot 100(5)$

$2.098(6)$

$2.063(6)$

2.061 (6)

2.051 (6)

$2.052(6)$

2.056 (6)

1.600 (4)

179.7 (2)

$90.6(2)$

90.2 (2)

$89.8(2)$
$89.6(2)$

$90 \cdot 1(2)$

$00.0(2)$

$89 \cdot 2(2)$

90.0 (2)

$179.6(2)$

$90.1(2)$

89.8 (2)

$79 \cdot 3(2)$

90.0 (2)

$90.5(2)$

$102 \cdot 7$ (2)

$102 \cdot 8$ (3)

$120 \cdot 3(5)$

$120 \cdot 3(5)$

$120 \cdot 3(6)$

$119 \cdot 6(5)$

$122.6(4)$

119.6 (5)

$117 \cdot 8(4)$
$119 \cdot 3(5)$

$118 \cdot 2(4)$

$122 \cdot 3$ (4)

$120 \cdot 7$ (5)

$120 \cdot 1(5)$

119.8 (6)

$120.6(5)$

122.9 (4)

$117 \cdot 7$ (4)

$119 \cdot 3(5)$

118.4 (4)

121.8 (4)

$119.8(5)$
$108.2(5)$

$1.403(8)$

$1.406(9)$

$1.429(9)$

$1.400(9)$

$1.415(8)$

$108 \cdot 0(5)$

$107.4(5)$

108.4 (6)

108.0 (5)

$1-2-3$

the FeCp moiety was located inside the heterocyclic fold and that the dihedral angle of the thianthrene skeleton in that complex was $127.4(3)^{\circ}$. In the present study, (I) was obtained by a different synthesis, via a photolytic monodemetallation reaction. A $1: 1$ mixture of conformers of the thianthrene complex with the $\mathrm{FeCp}$ moiety located inside and outside the heterocyclic fold was obtained. The dihedral angles of conformers $A$ and $B$ are 143.1 (2) and $136.3(2)^{\circ}$ for the in- and out-of-fold $\mathrm{FeCp}$ moieties. A significant increase in the dihedral angle $\left(\mathrm{ca}^{\circ}\right)$ is thus observed for the conformer having the $\mathrm{FeCp}$ inside the fold which could be attributed to a repulsion between the uncoordinated arene ring and the

$\begin{array}{cr}1-2 & 1-2-3 \\ 2.079(5) & \\ 2.077(6) & \\ 2.072(6) & \\ 2.077(6) & \\ 2.092(5) & \\ 2.081(5) & \\ 2.055(7) & \\ 2.038(6) & \\ 2.042(6) & \\ 2.054(6) & \\ 2.052(6) & \\ 1.593(3) & 179 \cdot 6(2) \\ & 90.7(2) \\ & 89.6(2) \\ & 90.1(2) \\ 1.601(3) & 89.6(2) \\ & 90.1(2) \\ & 89.6(2) \\ & 90.3(2) \\ 1.585(4) & 89.8(2) \\ & 179 \cdot 1(2) \\ & 90.5(2) \\ 1.597(3) & 89.8(2) \\ & 179.5(2) \\ & \end{array}$


Table 2 (cont.)

\begin{tabular}{|c|c|c|c|c|}
\hline 1 & 2 & 3 & $1-2$ & $1-2-3$ \\
\hline F5 & $\mathbf{P}$ & F6 & $1.587(4)$ & $89 \cdot 8(2)$ \\
\hline F6 & $\mathbf{P}$ & F1 & $1 \cdot 594(3)$ & $90.0(2)$ \\
\hline $\mathrm{C} 4 \mathrm{~A}$ & S5 & $\mathrm{C} 5 A$ & $1.769(5)$ & $100 \cdot 6(2)$ \\
\hline C5A & S5 & & $1 \cdot 760(5)$ & \\
\hline C9A & $\mathrm{S} 10$ & C10A & $1.767(6)$ & $100 \cdot 4(2)$ \\
\hline $\mathrm{C} 10 \mathrm{~A}$ & S10 & & $1.767(5)$ & \\
\hline $\mathrm{C} 2$ & $\mathrm{Cl}$ & $\mathrm{C} 10 \mathrm{~A}$ & 1.392(8) & $121 \cdot 0(5)$ \\
\hline $\mathrm{C} 10 A$ & $\mathrm{Cl}$ & & $1.401(8)$ & \\
\hline $\mathrm{C} 3$ & C2 & $\mathrm{Cl}$ & 1.396 (8) & $120 \cdot 0(5)$ \\
\hline $\mathrm{C} 4$ & C3 & C2 & $1 \cdot 392(8)$ & $120 \cdot 5(5)$ \\
\hline $\mathrm{C} 4 \mathrm{~A}$ & C4 & C3 & $1.423(8)$ & $120 \cdot 2(5)$ \\
\hline $\mathrm{C} 10 \mathrm{~A}$ & $\mathrm{C} 4 \mathrm{~A}$ & S5 & $1.426(6)$ & $120 \cdot 7(4)$ \\
\hline $\mathrm{ClOA}$ & $\mathrm{C} 4 A$ & C4 & & $118.8(5)$ \\
\hline S5 & $\mathrm{C} 4 \mathrm{~A}$ & $\mathrm{C} 4$ & & $120.1(4)$ \\
\hline C6 & C5A & $\mathrm{C} 9 \mathrm{~A}$ & $1.391(8)$ & {$[18.8(5)$} \\
\hline C6 & $\mathrm{C} 5 A$ & S5 & & $119.4(4)$ \\
\hline $\mathrm{C} 9 A$ & $\mathrm{C} 5 \mathrm{~A}$ & S5 & $1 \cdot 388(7)$ & $121 \cdot 7(4)$ \\
\hline C7 & C6 & C5A & $1 \cdot 387(8)$ & $120 \cdot 9(5)$ \\
\hline C8 & C7 & C6 & $1.385(8)$ & $119.8(6)$ \\
\hline C9 & $\mathrm{C} 8$ & $\mathrm{C7}$ & $1.382(9)$ & $119 \cdot 7(5)$ \\
\hline $\mathrm{C} 9 \mathrm{~A}$ & C9 & C8 & $1 \cdot 387(8)$ & $120 \cdot 6(5)$ \\
\hline SI0 & C9A & $\mathrm{C} 5 \mathrm{~A}$ & & $120 \cdot 7(4)$ \\
\hline SI0 & $\mathrm{C} 9 \mathrm{~A}$ & C9 & & $119.0(4)$ \\
\hline C5A & $\mathrm{C} 9 \mathrm{~A}$ & C9 & & $120 \cdot 3(5)$ \\
\hline S10 & $\mathrm{C} 10 \mathrm{~A}$ & $\mathrm{Cl}$ & & $120 \cdot 2(4)$ \\
\hline$\$ 10$ & $\mathrm{ClOA}$ & $\mathrm{C} 4 \mathrm{~A}$ & & $120 \cdot 1(4)$ \\
\hline $\mathrm{Cl}$ & $\mathrm{C} 10 \mathrm{~A}$ & $\mathrm{C} 4 \mathrm{~A}$ & & $119.4(5)$ \\
\hline $\mathrm{C} 12$ & $\mathrm{Cll}$ & $\mathrm{C} 15$ & $1.403(10)$ & $107 \cdot 4(5)$ \\
\hline $\mathrm{C} 15$ & C11 & & $1.402(9)$ & \\
\hline $\mathrm{Cl3}$ & $\mathrm{C} 12$ & C11 & $1 \cdot 397(8)$ & $108.9(6)$ \\
\hline $\mathrm{Cl} 4$ & $\mathrm{Cl} 3$ & $\mathrm{C} 12$ & $1.410(9)$ & $107 \cdot 3(5)$ \\
\hline $\mathrm{Cl5}$ & $\mathrm{Cl} 4$ & $\mathrm{C} 13$ & $1.399(8)$ & $108 \cdot 1(5)$ \\
\hline $\mathrm{Cll}$ & $\mathrm{C} 15$ & $\mathrm{C} 14$ & & $108 \cdot 3(6)$ \\
\hline
\end{tabular}

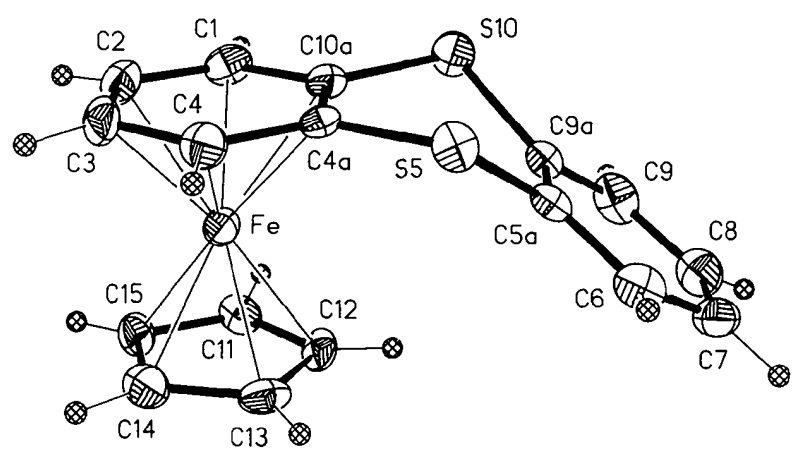

Fig. 1. 50\% thermal ellipsoid drawing of molecule $A$.

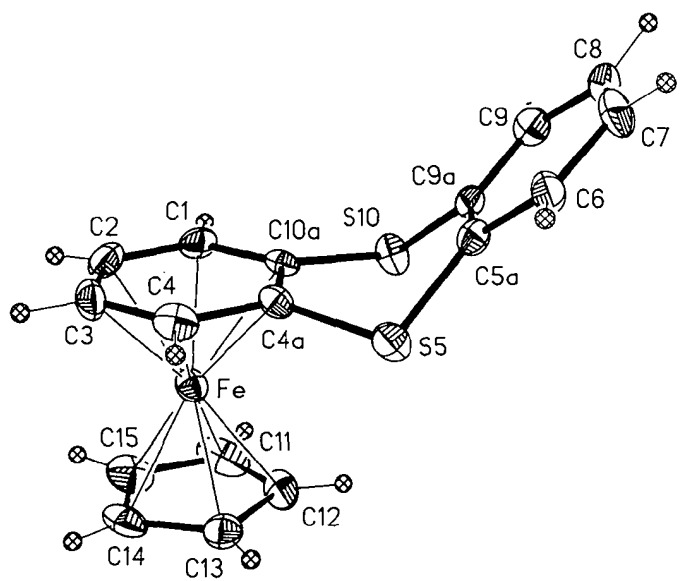

Fig. 2. $50 \%$ thermal ellipsoid drawing of molecule $B$.
$\mathrm{Cp}$ ring. The dihedral angle of the 2-methylthianthrene complex, for which a similar repulsion should exist, was slightly smaller than that of thianthrene (Larson, Simonsen, Martin, Smith \& Puig-Torres, 1984) $\left[127.4(3)\right.$ vs $\left.128.7(7)^{\circ}\right]$. Three other factors should be considered: (1) $\mathrm{FeCp}$ is an electronwithdrawing group which would tend to flatten the heterocycle, (2) the methyl substituent on the arene ring is an electron-releasing group which would exert the opposite effect, and (3) packing forces. The difference in the dihedral angles of (I) and (II) must be due to the influence of the methyl group which counteracts the $\mathrm{FeCp}$ complexation effect.

The method of synthesis of (I) resulted in a 1:1 ratio of two conformers, whereas the 2-methylthianthrene complex, prepared by a different synthetic route, yielded only the in-fold conformer. To ascertain whether both conformers were formed in the latter synthesis, a dynamic ${ }^{1} \mathrm{H}$ NMR study in the range of $175-370 \mathrm{~K}$ was carried out. The spectrum remained unchanged at all temperatures, indicating only one conformer or, perhaps, ring flipping. However, the co-crystallization of the two conformers of (I) seems to indicate that both of them produced in the reaction remain stable at and below room temperature (both synthetic routes are completed at room temperature) with no ring flipping.

The $\mathrm{PF}_{6}^{-}$groups are reasonably well behaved with the $\mathrm{P}-\mathrm{F}$ bond distances ranging between 1.598 (4) and $1.610(3) \AA$ in $A$ and $1.585(3)$ and 1.601 (3) $\AA$ in $B$. No $\mathrm{F}-\mathrm{P}-\mathrm{F}$ angle deviates from the octahedral geometry by more than $0.6^{\circ}$ in $A$ and $0.7^{\circ}$ in $B$.

Currently, we are involved in further work which should clarify the stereochemistry of formation of heterocycle complexes in a double nucleophilic sub-

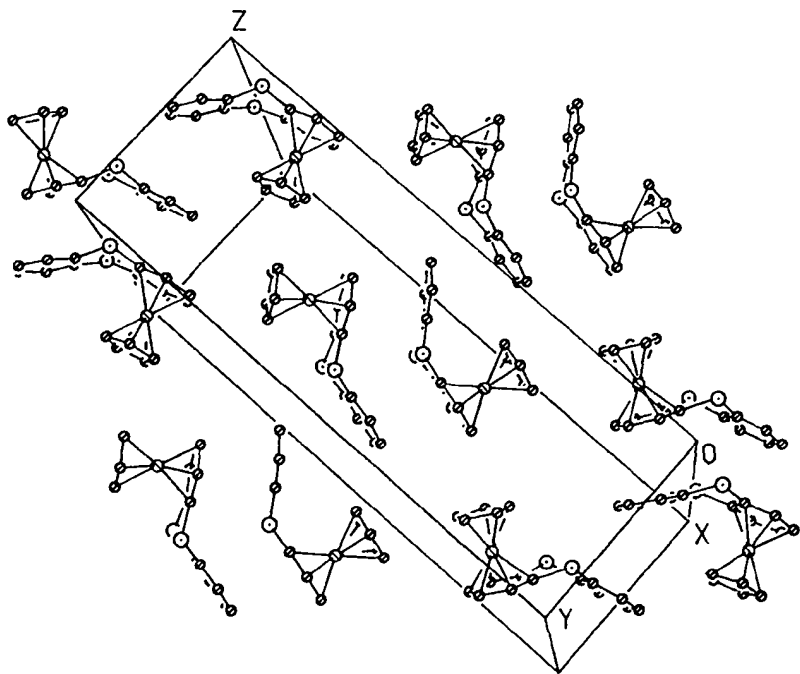

Fig. 3. Packing diagram of (I). 
stitution reaction and the influence of substituents on the molecule folding.

This research was supported by the Robert A. Welch Foundation Grant F-017 (SHS), and the Natural Sciences and Engineering Research Council of Canada (RGS). KAA would like to thank Robert LaMont for his help in structure refinement.

\section{References}

Cordes, A. W. (1983). Personal communication.

Cromer, D. T. \& Liberman, D. (1970). J. Chem. Phys. 53, 1891-1898.

Cromer, D. T. \& ManN, J. B. (1968). Acta Cryst. A24, 321-324.

GADOL, S. M. \& DAVIS, R. E. (1982). Organometallics, 1, 1607-1613.
International Tables for X-ray Crystallography (1974). Vol. IV, p. 55. Birmingham: Kynoch Press. (Present distributor Kluwer Academic Publishers, Dordrecht.)

Larson, S. B., Simonsen, S. H., Martin, G. E., Smith, K. \& PUIG-TORRES, S. (1984). Acta Cryst. C40, 103-106.

Lee, C. C., Piórko, A. \& Sutherland, R. G. (1983). J. Organomet. Chem. 248, 357-364.

Lynch, V. M., Thomas, S. N., Simonsen, S. H., Piórko, A. \& Sutherland, R. G. (1986). Acta Cryst. C42, 1144-1148.

Rilex, P. E. \& Davis, R. E. (1976). Acta Cryst. B32, 381-386.

Sheldrick, G. M. (1976). SHELX76. Program for crystal structure determination. Univ. of Cambridge, England.

SHELDRICK, G. M. (1987). SHELXTL-PLUS. Nicolet XRD Corporation, Madison, Wisconsin, USA.

Simonsen, S. H., Lynch, V. M., Sutherland, R. G. \& Piórko, A. (1985). J. Organomet. Chem. 290, 387-400.

Stewart, R. F., Davidson, E. R. \& Simpson, W. T. (1965). $J$. Chem. Phys. 42, 3175-3187.

Sutherland, R. G., Piórko, A., Gill, U. S. \& Lee, C. C. (1982). J. Heterocyl. Chem. 19, 801-803.

Acta Cryst. (1990). C46, 1022-1025

\title{
Relationship Between X-ray Structure and Phosphodiesterase Activity of Co ${ }^{\mathrm{III}}$ Complexes: Structure of Dinitro[tris(2-aminoethyl)amine]cobalt(III) Chloride
}

\author{
By JiK ChIN* AND MaRC DROUIN \\ Department of Chemistry, McGill University, Montreal, Canada, H3A 2K6
}

AND ANDRÉ G. MICHEL*

Laboratoire de chimie structurale, Département de chimie, Faculté des Sciences, Université de Sherbrooke, Sherbrooke, Québec, Canada, J1K 2R1

(Received 10 July 1989; accepted 9 January 1990)

\begin{abstract}
Co}\left(\mathrm{NO}_{2}\right)_{2}\left(\mathrm{C}_{6} \mathrm{H}_{18} \mathrm{~N}_{4}\right)\right] \mathrm{Cl}, M_{r}=332 \cdot 6$, orthorhombic, $P c m b, a=8.452$ (6), $b=12.0735$ (4), $c=$ $12.1733(8) \AA, V=1242 \cdot 23 \AA^{3}, D_{x}=1.778 \mathrm{Mg} \mathrm{m}^{-3}$, $Z=4, \quad \lambda($ Mo $K c)=0.71069 \AA, \quad \mu=1.61 \mathrm{~mm}^{-1}$, $F(000)=687.80$, room temperature, final $R=0.024$ for 749 reflections in the range $00.00<2 \theta<47.90^{\circ}$. All of the cis $\mathrm{N}-\mathrm{Co}-\mathrm{N}$ bond angles in the parent compound are essentially the same as the corresponding angles in $\left[(\operatorname{tren}) \mathrm{Co}\left(\mathrm{CO}_{3}\right)^{+}\right.$[tren: tris $(2-$ aminoethyl)amine]. In sharp contrast, one of the cis $\mathrm{N}-\mathrm{Co}-\mathrm{N}$ bond angles increases dramatically on going from $\left[(\text { cyclen }) \mathrm{Co}\left(\mathrm{NO}_{2}\right)_{2}\right]^{+}$to $[$(cyclen)$\left.\mathrm{Co}\left(\mathrm{CO}_{3}\right)\right]^{+}$(cyclen: 1,4,7,11-tetraazacyclododecane). Relative reactivity of $\left[(\text { tren }) \mathrm{Co}\left(\mathrm{OH}_{2}\right)(\mathrm{OH})\right]^{2+}$ and $\left[(\text { cyclen }) \mathrm{Co}\left(\mathrm{OH}_{2}\right)(\mathrm{OH})\right]^{2+}$ in hydrolyzing phosphate diesters is explained in terms of the cis $\mathrm{N}-\mathrm{Co}-\mathrm{N}$ bond angle.
\end{abstract}

Introduction. Currently there is much interest in designing catalysts that hydrolyze the phosphate di-

\footnotetext{
* Authors to whom correspondence should be addressed.
}

0108-2701/90/061022-04\$03.00 ester backbone of DNA (Dervan \& Moser, 1987). We recently showed that cis aquahydroxo(tetraamine)Co ${ }^{\text {III }}$ complexes are highly efficient at hydrolyzing phosphate diesters (Chin \& Zou, 1988). Furthermore, the reactivity of $\mathrm{Co}^{\text {III }}$ complexes is extremely sensitive to the tetraamine ligand structure (Chin, Banaszczyk, Jubian \& Zou, 1989; Chin \& Banaszczyk, 1989a,b). For example, the phosphate diester bond in (1) is hydrolyzed about 50 times more rapidly than that in (2). In order to find out why (1) is so much more reactive than (2), we determined the crystal structure of $\left(2^{\prime}\right)$ (see Fig. 1).

Experimental. [(tren) $\left.\mathrm{Co}\left(\mathrm{NO}_{2}\right)_{2}\right] \mathrm{Cl}$ was prepared from [(tren) $\left.\mathrm{CoCl}_{2}\right] \mathrm{Cl}$ following the procedure described for the preparation of $\left[(\mathrm{en})_{2} \mathrm{Co}\left(\mathrm{NO}_{2}\right)_{2}\right] \mathrm{Cl}$ (Bernal, 1985). Anal. calc. for $\left[\mathrm{Co}\left(\mathrm{C}_{6} \mathrm{H}_{18} \mathrm{~N}_{4}\right)\left(\mathrm{NO}_{2}\right)_{2}\right] \mathrm{Cl}$ : C 21.68, $\mathrm{H}$ $5 \cdot 46$, N 25.39\%. Found: C 22.06, H 5.25, N 25.66\%.

The X-ray diffraction was performed on an orange rectangular crystal, $0.20 \times 0.20 \times 0.25 \mathrm{~mm}$; EnrafNonius CAD-4 diffractometer with graphite monochromator and Mo $K \alpha$ radiation. The cell dimen(c) 1990 International Union of Crystallography 